\title{
Virtual Laboratories for Physical Programming: Its Importance and Challenges
}

\author{
http://dx.doi.org/10.3991/ijes.v2i3.3823 \\ S. C. C. Porto ${ }^{1}$, G. da S. Cruz ${ }^{1,2}$ and F. R. Santos ${ }^{1}$ \\ ${ }^{1}$ Instituto Federal de Educação Ciência e Tecnologia da Bahia, Jacobina, Brasil \\ ${ }^{2}$ Universidade Salvador, Feira de Santana, Brasil
}

\begin{abstract}
The information and communication technologies (ICTs) in educational environments are designed to provide educational institutions, tools that aid the process of teaching and learning in a motivating and interactive way. Laboratory of Physics, viewed as a place of exchange and collaborations, the internet has among other technological tools an important tool to promote learning through activities that involve the manipulation of objects, which in this case are virtual nature. This article presents the virtual laboratory in a teaching perspective that utilizes the potential of this environment for the development of nature "practice" activities, in contrast with laboratories using concrete elements.
\end{abstract}

Index Terms-learning, laboratory concrete, virtual, physical

\section{INTRODUCTION}

The benefits of computer use in the teaching- learning process are fairly discussed, since the dissemination of this technological resource. On teacher performance in the classroom, it is easily seen how certain content of physics are best understood from the preview images generated in software or through actual images of physical phenomena. These physical events could be due to natural phenomena or created in the laboratory experiments. According to Ribas, Barone and Basso [2007], there is a satisfaction and safety of students when there is a reference to his discipline available anytime and easy access. On a site it is possible to find the hours, days and times of classes, the classroom where the lecture, menu and schedule of discipline, support materials, exercises, bibliographies, interesting links, teacher portal, student portal will occur among others.

Using an access controller in a particular site, it is easily verified that increasingly students are accustomed to seek particular information on the internet. The use of Information Technology and Communication (ICT) offer a wider range of educational resources, favoring the construction of knowledge by the student, resulting from the interaction with the object and does not transmitted by the teacher [Amaral et al, 2011].

\section{LITERATURE REVIEW}

There is a current of opinion, that associates the educational deficit of the vast majority of students, the lack of lab classes [Borges, 2002]. Thus, it is mister, assembly of laboratories that include subjects worked in the classroom as well as the training of teachers to be trained to perform laboratory activities with students. O use of computer technologies and communication has grown in all sectors of human activity, seeking to provide new understandings about these technologies. Are seen by most people as instruments of social inclusion and cultural recreation therefore approached by contemporary cultures can create new fields of knowledge and merge existing fields [GIORDAN, 2008].

\section{THEORETICAL FRAMEWORK ON THE USE OF COMPUTERS IN THE PHYSICS LABORATORY}

The use of new technologies is the subject of frequent discussion among researchers. The presence of Information Technology and Communication (ICT) seeks to structure a new dynamic relationship in the world. To Lapa, Hohenfed and Penido [2007, p.2] provides "... a quantum leap in education particularly in science education, where teaching practices can advance qualitatively using these aspects contribute to the formation of citizens." For these authors, the spread of information and communication technologies is due to technological advancement and cost of microelectronic components.

In this same line of reasoning Veit and Araujo [2005, p.5] argue that,

...Computer simulations with pedagogical objectives support the exploratory activities characterized by observation and analysis of the subject interact with models already constructed. Computer modeling applied to the teaching of physics is developed in expressive activities, characterized by the model building process since its mathematical structure to the analysis of the results generated by it.

However, these authors when ICTs are used without a theoretical framework for learning, it may result in an error similar to that done with books and other educational resources. Meiguins et al [2011, pag.3] comments:

(...) The potential of virtual environments are in fact permit, a new and different way that people can do things they could not do in the physical world, such as flying, visiting places that do not exist or are difficult to access, through the manipulation and analysis of the object of study.

The virtual modeling arises from the ease with which students have to use their prior knowledge, the result of their everyday experiences with the real world.

\section{THEORETICAL FRAMEWORK ABOUT PROGRAMMING IN PHYSICS LAB}

A virtual lab named based on the use of simulations, models and views. Some authors do not call the lab, de- 
spite being designed to meet some of the assumptions of a real lab. This is not to say that a virtual lab is able to replace and meet the expectations of a real lab. The virtual laboratory can enhance and complement the function of a real lab. A virtual laboratory may enable the realization of experiments, the actual laboratories are not able to perform due to lack of appropriate experimental apparatus suitable environmental conditions for the observation of physical phenomena and teacher training that will guide students. Souza, Oliveira and Santos [2001, p. 3] argues that " Laboratories with purely virtual content could be used for conducting experiments that would function as preparatory activity for a real lab. Thus the student would attend to the real class having already handled concepts and views related to the activity to be developed. "

\section{General Purpose}

Assess the ability of students of technical computer courses from Jacobina IFBA have to program virtual laboratories for Physics;

A. Specific

- Set virtual laboratories for Physics in order to subsidize the lectures of Physics Campus Jacobina in Bahia Federal Institute of Technology and Education;

- Discussing their relevance to physics classes with the help of a virtual laboratory;

- Create virtual physics experiments that are not available in the internet network;

- Create scripts for virtual laboratories for Physics programmed;

- Measure the level of learning content by students of Physics scheduling virtual laboratories for Physics.

\section{RATIONALE}

The benefits arising from the use of computers in the educational process are easily observed by educators, so it is appropriate questioning. Computers can be used to work with instructional materials that pose challenges in the physics lab? After all, now make use of computational resources is much more affordable to have a properly equipped laboratory for use by teachers of physics. These limitations include not only the school but also the possible local frequency environments students. Mounting a physics lab with virtual activities and work it as an educational tool is of great relevance to educators and students. Thus this project aims to address the process of teaching learning of students who schedule virtual laboratories for Physics. Table I describes the implementation schedule of the research.

\section{Methodology AND DATA COLlECtion}

The work will be developed with two students from a course in Computer subsequent form, who are attending the last year of academic training. The optics and astronomy were chosen as the content, the difficulty of reproducing laboratory experiments and affinity of the students who will make the schedules. Optics and Astronomy are matters of everyday life and to arouse the curiosity of many observers and scholars, besides having not available on the internet virtual laboratories on such varied content network.
TABLE I.

IMPLEMENTATION SCHEDULE

\begin{tabular}{|l|l|l|}
\hline \multicolumn{1}{|c|}{ Activities to be undertaken } & $\begin{array}{c}\text { First Half of } \\
\mathbf{2 0 1 3}\end{array}$ & $\begin{array}{l}\text { Second Semes- } \\
\text { ter 2013 }\end{array}$ \\
\hline $\begin{array}{l}\text { Definition of the content used in the } \\
\text { programs along with students having } \\
\text { the choice as affinity parameter. }\end{array}$ & & \\
\hline $\begin{array}{l}\text { The questionnaires probing by the } \\
\text { teacher of the school unit. }\end{array}$ & & \\
\hline $\begin{array}{l}\text { Scheduling of virtual labs with ac- } \\
\text { companying teacher of Physics at } \\
\text { school unit. }\end{array}$ & & \\
\hline $\begin{array}{l}\text { Presentation of the settings made by } \\
\text { the students of the school physics } \\
\text { teacher unit. }\end{array}$ & & \\
\hline $\begin{array}{l}\text { Virtual testing lab designed by stu- } \\
\text { dents at school physics teacher unit. }\end{array}$ & & \\
\hline $\begin{array}{l}\text { Application of an investigative ques- } \\
\text { tionnaire on students who made } \\
\text { schedules. }\end{array}$ & & \\
\hline $\begin{array}{l}\text { Analysis and presentation of data } \\
\text { collected through the survey question- } \\
\text { naire and investigative activities. }\end{array}$ & & \\
\hline
\end{tabular}

\section{EXPECTED OUTCOMES}

The computer follows the emergence of new technologies, which have contributed to changes that occur in various sectors among this education. The teacher student relationship has become much more dynamic and collaborative in recent years. The teacher has left the role of mere transmitter and assumed the position of guiding, encouraging students to construct their concepts, enabling the development of skills and competencies. The question motivation is of fundamental importance for the intellectual growth of the individual, because for that learning is fostered is necessary that the teacher provide an academic environment that causes students to create, compare, reflect, discuss, question and extend their knowledge. It is hoped that the methodology used in this project with the use of technological resources, fosters student learning using computers to program virtual labs. Where the cognitive ability of a student can be ascertained in various ways, either through written evaluations closed and open, oral or practical activity questionnaire.

\section{REFERENCES}

[1] AMARAL Érico M. H., Ávila Bárbara, ZEDNIK, Herik, TAROUCO, Liane, Laboratório Virtual de Aprendizagem: Uma Proposta Taxonômica. Disponível em: http://seer.ufrgs.br Acesso em 24 de abr. de 2013.

[2] BORGE, A, Antonio T., Novos Rumos para o Laboratório Escolar de Ciências. Disponível em: <http://www.fsc.ufsc.br $>$ Acesso em 24 de abr. de 2013.

[3] GIORDAN, Marcelo. Computadores e linguagens nas aulas de CIÊNCIAS. Ijuí: Ed. Unijuí, 2008. 328 p. ISBN: 9788574296852. Disponível em: < http://qnesc.sbq.org.br $>$ Acesso em 24 de abr. de 2013.

[4] LAPA, J. M.; HOHENFELD, D. P., PENIDO, M. C. M.-A Formação do Professor de Física e as Tecnologias da Informação e Comunicação. Disponível em $<$ http://publicacoes.unigranrio.edu.br>. Acesso em 22 de set. 2013

[5] MEIGUINS, Bianchi S., BEHRENS, Frank H., MEIGUINS, Breno S., FERREIRA, Daniel O.. Tecnologia de Realidade Virtual para o Auxílio no Aprendizado em Sala de Aula para Circuitos Elétricos - Disponível em: http://www.cafw.ufsm.br Acesso em 23 de abr. de 2013. 
[6] RIBAS, Daniela R., BARONE, Dante Augusto C., BASSO, Marcus Vinicius de A., O Uso de um Laboratório Virtual de Matemática no Processo de Ensino-Aprendizagem - Disponível em: < http: www.cinted.ufrgs.br> Acesso em 25 de abr. de 2013

[7] SOUZA, Antonio L. de., OLIVEIRA, José Carlos de., SANTOS, Marcelo Paulino de L., Recursos da Computação Gráfica para o Desenvolvimento de um Laboratório Virtual de Teoria Eletromagnética- Disponível em: < http://www.abenge.org.br>, Acesso em 23 de abr.

[8] VEIT, E. A.; ARAUJO, I.S. Modelagem Computacional no Ensino de Física. In: Revista do Centro de Educação da Universidade Federal de Alagoas. CEDU - n.21 - Maceió: Imprensa Universitária. UFAL. 2004. Disponível em: <http://www.if.ufrgs.br> Acesso em 27 de abr. de 2013

\section{AUTHORS}

S.C.C. PORTO, an official of the Federal Institute of Bahia, Centennial Avenue, Nazareth Neighborhood, 500, CEP 44700-000, Jacobina, Bahia (e-mail: silviaporto@ifba.edu.br).
G. da S. CRUZ, worked at the Federal Institute of Bahia, located at Avenida Centenario, Neighborhood Nazareth, 500, CEP :44700-000, Jacobina, Bahia until January 2014, is currently official Salvadorlocalizada University Street in Rio Tinto, Neighborhood Santa Monica, 152 Cep 44052-250 Feira de Santana, Bahia(e-mail: gigedo@gmail.com).

F.R. SANTOS, student of computer technician in subsequent embodiment, the Federal Institute of Bahia, Centennial Avenue, Nazareth Neighborhood, 500, CEP 44700-000, Jacobina, Bahia (e-mail: fagnaestrela@hotmail.com).

This article is an extended and modified version of a paper presented at the ICBL2013 International Conference on Interactive Computer aided Blended Learning, held 6 - 8 November 2013, in Florianópolis, Brasil. Submitted 29 April 2014. Published as resubmitted 07 August 2014. 